\title{
Corporate social responsibility and the market valuation of listed real estate investment companies
}

\author{
Alexander Nikolaus Kerscher • Wolfgang Schäfers
}

(C) The Author(s) 2015. This article is published with open access at Springerlink.com

\begin{abstract}
This study investigates the relationship between the implementation of a corporate social responsibility (CSR) strategy and the corporate financial performance of listed real estate investment companies. The sustainability of a company is measured using various self-constructed indices based on the Guidelines of the Global Reporting Initiative (GRI). Overall, a positive relationship can be established. An over-reporting of sustainability information dilutes this relationship. Furthermore, investors value initiatives which have a clear and coherent link to the enhancement of future value creation processes such as efforts to mitigate environmental impacts by reducing resource and energy consumption of buildings. A two-stage least squares regression framework is used to account for the problem of endogeneity.
\end{abstract}

Keywords Corporate social responsibility - Global Reporting Initiative · Listed real estate $\cdot$ Real Estate Investment Trusts $\cdot$ GRI $\cdot$ CSR $\cdot 2$ SLS · Instrumental Variables · Component-wise Gradient Boosting

\section{Corporate Social Responsibility und die Marktbewertung von börsennotierten Immobilienaktiengesellschaften}

Zusammenfassung Die vorgelegte Studie untersucht den Zusammenhang zwischen der Implementierung einer Corporate Social Responsibility (CSR) Strategie und der

\footnotetext{
A. N. Kerscher $(\bowtie) \cdot$ W. Schäfers

Lehrstuhl für Immobilienmanagement, IRE|BS Institut für Immobilienökonomie, Universität Regensburg,

Universitätsstraße 31,

93040 Regensburg, Germany

e-mail: alexander.kerscher@irebs-core.de

W. Schäfers

e-mail: wolfgang.schaefers@irebs.de
} 
finanziellen Performance von börsennotierten Immobilienunternehmen. Zur Messung des Grades der Nachhaltigkeit eines Unternehmens werden Indizes herangezogen, welche auf den Guidelines der Global Reporting Initiative (GRI) basieren. Insgesamt kann ein positiver Zusammenhang festgestellt werden. Eine übermäßige Veröffentlichung von Informationen zur Unternehmensnachhaltigkeit verwässert diesen $\mathrm{Zu}$ sammenhang. Investoren schätzen insbesondere Nachhaltigkeitsinitiativen, welche einen eindeutigen und kohärenten Bezug zu einer Verbesserung zukünftiger Wertschöpfung aufweisen. Beispiele für solche Initiativen sind die Verminderung von negativen Auswirkungen auf die Umwelt durch Reduktion von Ressourcen- und Energieverbrauch durch Gebäude. Um das Problem der Endogenität in der empirischen Untersuchung zu berücksichtigen, wird eine zweistufige Regression durchgeführt.

Schlüsselwörter Corporate social responsibility · Nachhaltigkeit ·

Global Reporting Initiative · Immobilien - Real Estate Investment Trusts · GRI · CSR · 2SLS · Instrumental Variables · Component-wise Gradient Boosting

\section{Introduction}

For long periods in history, societal needs and claims were largely neglected by governments and business. However, in the wake of increasing democratization and progressing socioeconomic development in wide parts of Western societies, power relations have undergone considerable change (van Marrewijk 2003). Over time, civil society has gained substantial power which is channeled through NGOs and public organizations. Today, corporations face an increased level of scrutiny from various stakeholders and find themselves as part of a complex nexus of distinctive interest groups. In this context, the most pressing drivers of change in societal expectations on business stem from increasing environmental awareness and increasing consumption alongside a shrinking supply of natural resources and geopolitical changes (McKinsey and Company 2007). In order to ensure their long-term viability, corporations have no choice but to adapt to society's changed expectations and to identify new approaches to strategic management that can meet the challenges thus posed.

As the environmental, social and political developments of recent decades unfolded, the concept of corporate social responsibility (CSR) attracted more and more attention among business leaders. While there is still much debate on what actually constitutes CSR and how it should be integrated into the conduct of business, business leaders across the board agree on one key insight: that CSR matters and, as a result, warrants incorporation into their company DNA. Indeed, the incorporation of CSR is seen as one of the most important leadership challenges for business today. A growing number of organizations promoting a sustainable approach towards strategic management such as the United Nations Global Compact, the International Organization for Standardization or GRI lend support to this observation. A further case in point is the fact that there are only a few, if any, high-profile listed corporations that have not yet made their CSR initiatives a permanent feature of their annual report. 
In view of the rising number of real estate investment trusts (REITs) and the incessant growth of listed real estate operating companies (REOCs) increasingly gaining influence in the sector, the real estate investment industry cannot afford to ignore these global trends. Porter and Kramer (2006) argue that a company has the obligation to contribute to the solution of societal problems where these coincide with its specific business. There is little doubt that environmental issues are the areas in which the real estate investment industry can contribute the most. According to various sources, buildings are responsible for about $40 \%$ of energy consumption and greenhouse gas emissions worldwide (UNEP 2009; USGBC 2008). Unsurprisingly, governments have identified buildings as a major lever in the fight against climate change and continue to impose stricter laws and regulations in order to reduce their consumption of energy. Besides more general social areas like, for example, labor practices, the core business of listed real estate investment companies intersects with the expectations of society where public open spaces are concerned. As a consequence, the pro-active integration of CSR into the strategic management of listed real estate investment companies appears to be a reasonable response to today's urgent and important challenges.

In addition to the aforementioned social and environmental reasons, another major driver for this development is the growing volume of responsibly managed assets belonging to institutional investors. Given the fact that institutional investors are by far the largest shareholders of listed real estate investment companies, meeting their requirements is all the more important for publicly traded companies. According to the Global Sustainable Investment Alliance (2013), the volume of socially responsibly managed assets in Europe grew by $22.5 \%$ from USD 7.15 trillion at the end of 2009 to USD 8.76 trillion at the end of 2011 . This figure represents around $49 \%$ of all professionally managed assets in Europe.

Consequently, listed companies in general and listed real estate investment companies in particular are seen to increasingly adopt the reporting guidelines provided by the GRI in order to enhance their transparency with regard to CSR. The number of worldwide issued GRI-aligned CSR reports rose from about 540 in 2006 to about 2600 in 2012. In the course of the same year, 75 companies from the real estate industry reported in line with the GRI framework (GRI 2014).

In this context, it is import to know if enhanced integration of CSR into core business functions positively affects the market valuation of a listed real estate investment company. In order to make strategic investment decisions, business executives of listed real estate investment companies need to know whether the integration of CSR into core business functions is appreciated and rewarded by investors through higher stock market valuations. This study contributes to the current debate on the profitability of CSR engagements by listed real estate investment companies. It employs a sophisticated method to identify the most value relevant CSR areas for an eminently homogenous sample of REITs and REOCs from nine different countries.

\section{Literature review}

The relationship between corporate social performance (CSP) and corporate financial performance (CFP) has been discussed and empirically examined in various studies 
in the past. Probably the most prominent study using meta-analysis techniques to investigate the results of various underlying studies on the CSP-CFP link is conducted by Orlitzky et al. (2003) who meta-analyze 52 studies published between 1976 and 1997. Based on a positive average effect-size of 0.184 they conclude that there exists an overall positive association between CSP and CFP. ${ }^{1}$ This finding holds across industries and study contexts. Nevertheless, the generally positive association between CSP and CFP is mitigated by the choice of CSP and CFP measures as well as the chosen form of operationalization. Thus, the positive relationship between CSP and CFP fluctuates from highly positive to modestly positive across studies. Moreover, the authors find no differences in the relationship between CSP and CFP when the studies under examination employ lagged values for the variables of interest. Furthermore, the authors suggest that this finding contradicts the trade-off theory which posits that a company which engages in CSR eventually suffers financial losses.

The most comprehensive meta-analysis using studies which investigate the CSPCFP link was carried out by Margolis et al. (2009). The researchers investigate 251 studies on the subject and confirm an overall positive association between CSP and CFP. The calculated weighted mean effect-size is 0.105 . Opposed to Orlitzky et al. (2003), the authors find different average effect-sizes when the temporal sequence is considered. In the studies under examination, the relationship between CSP and lagged CFP is higher than for lagged CSP and CFP. Nevertheless, this does not contradict the virtuous circle theory since both relationships are positive and significant.

Looking closely at some studies from the finance literature investigating the CSPCFP link yields further insight into the various sources of mitigating effects on the CSP-CFP relationship. In particular, there is evidence for a varying strength of this relationship based on the choice of CSP and CFP proxies, the use of control variables and the application of lagged variables.

Callan and Thomas (2009) conduct a GMM regression using a lagged variable structure. The CSP measures in the equations are from 2004 and all other variables stem from 2005. By this means, the authors are able to draw causal inferences on whether prior CSP influences current CFP. Overall, they report a positive and statistically significant association between the used CSP measures and the CFP measures ROA, ROE and Tobin's Q, but not ROS.

A different approach to investigating the causal relationship between CSP and CFP is taken by Garcia-Castro et al. (2010) who examine the CSP-CFP link using various proxies for CFP. CSP is measured by an equally weighted KLD index. Employing OLS, they replicate the results of previous studies that a positive and statistically significant relationship exists between CSP and Tobin's Q, ROA, ROE and MVA. However, based on the results obtained from a fixed effects model they conclude that the positive CSP-CFP association traces back to unobserved variables. The authors find evidence for the presence of endogeneity. A subsequently conducted 2SLS estimation controls for the endogeneity problem and reveals that the initially positive association between CSP and CFP turns insignificant for all four measures of CFP.

\footnotetext{
${ }^{1}$ Within the reported meta-analyses, effect-size $r$ refers to an aggregate measure which is used to investigate the CSP-CFP relationship. It is calculated using the (partial) correlations between CSP and CFP or t-statistics reported in underlying studies.
} 
In 2011, Jo and Harjoto published a comprehensive research article providing evidence for a positive and very robust association between CSP and CFP. After controlling for simultaneity bias and endogeneity by using second-stage Heckman regression analysis and an instrumental variables approach, they find a positive relationship between CSP and CFP as measured by an industry-adjusted Tobin's Q. The authors take this as evidence for the confirmation of their proposed conflict-resolution theory. According to the conflict-resolution theory, agency conflicts are mitigated, because top-management enhances stakeholder relationships by engaging in CSR activities which in turn positively affects firm value.

Schreck (2011) is the first to use an aggregated CSP measure based on the sustainability scorings provided by oekom research AG, a German-based CSR rating agency. Moreover, decomposed measures which refer to single subcategories of CSR are employed. OLS regression analysis reveals that there is no generic positive association between CSP and CFP when the aggregate measure for CSP is used. However, the use of CSR subcategory measures shows that "Corporate Governance" and "Environmental Management" is positively and significantly associated with Tobin's Q. Neither the employed instrumental variables regression nor the Granger causality tests are able to establish a causal relation that runs from one of the CSR measures to Tobin's Q. The author concludes that the failure to establish a causal relation between CSP and CFP is predominantly due to the small sample size and limited data.

Erhemjamts et al. (2013) employ the method of OLS to investigate the relationship between CSP and CFP in an inter-industry sample. They find a positive relationship for the overall KLD score and CFP measured by Tobin's Q and ROA. Additionally, they use a decomposed KLD score as a proxy for CSP. CSR strengths (concerns) are positively (negatively) related to CFP. In order to account for the problem of endogeneity, the authors use instrumental variables and employ the method of 2SLS. The instruments pass the tests for instrument relevance and instrument exogeneity. However, in the case of the equations which include only one endogenous regressor (overall KLD), the researchers are not able to reject the null hypothesis of weak instruments since the corresponding F statistic is below the critical value of 10 as proposed by Stock and Watson (2007). Nevertheless, after controlling for endogeneity, the results of the OLS regression are confirmed.

The reviewed articles from the finance literature show that there are various ways of exploring the CSP-CFP link. The most important aspects of the selected studies relate to the operationalization of CSP and CFP as well as to the chosen method for investigating a possible link. In particular, it has become a common practice to account for endogeneity in studies analyzing the CSP-CFP link. Another important point is that the studies provide evidence for the appropriateness of Tobin's Q as a measure for CFP. However, only two of the reviewed studies from the finance literature employ an international data set. Hence, further research has to investigate the CSP-CFP link in a broader international framework.

Within the real estate literature the analysis of the CSP-CFP link is a rather new branch of research. Nevertheless, there are a number of articles which investigate the business case for CSR in the real estate industry. With regard to the measurement of CSP, Cajias et al. (2011) draw on an approach which has already been observed in the finance literature. Using a sample consisting of real estate service firms, development 
companies, real estate investment companies and REITs, the authors employ several CSR scores based on seven dimensions of the KLD database. The applied test yields no evidence for the presence of Granger causality. Nevertheless, the authors find that contemporary CSP as measured by an overall CSR score is associated with a higher CFP as measured by Tobin's Q. This effect is stronger for a weighted CSR score. For the CSR concerns score they find a negative relationship.

In another study Cajias et al. (2012) measure the CSP of a company by taking account of the amount and quality of reported sustainability information. Based on the GRI Guidelines, the researchers investigate 13 aspects of company reports covering the CSR subcategories "human rights and social responsibility", "environmental responsibility", "financial responsibility" and "transparency and disclosure quality". The authors find that companies engaging in and reporting on overall CSR issues are associated with a higher financial performance at present. In particular, a high performance in the field of employee relations exerts a significantly positive effect. Conversely, they find a negative relationship between the amount of disclosed real estate related sustainability information and asset turnover. The researches cite the high level of disclosure of real estate information which may disclose too much of a company's operating strategy to the public as one possible reason for this finding.

Among others, the most important benefits of certified buildings are higher transaction prices, higher rents and higher occupancy rates as compared to non-certified buildings (Dermisi 2009; Eichholtz et al. 2013; Fuerst and McAllister 2011; Reichardt et al. 2012). Eichholtz et al. (2012) find evidence that the financial benefits of investing into certified buildings also translate into an increased financial performance on a corporate level. The authors use LEED and ENERGY STAR certified portfolio space to determine the CSP of a REIT. After accounting for endogeneity, the researchers find that by increasing the share of LEED-certified buildings in the portfolio by $1 \%$ a REIT is able to enhance its ROS by approximately $3.5 \%$. A $1 \%$ increase of the share of ENERGY STAR-certified buildings in the portfolio is associated with a $0.5 \%$ increase of the REIT's ROA.

Another research article providing evidence for the translation of green buildings' superior financial performance into enhanced financial performance on the corporate level is provided by Sah et al. (2013). The authors differentiate between green REITs which are characterized by a corporate policy which is geared to sustainability and usual REITs. Accordingly, the proxy for CSP is introduced as a dummy variable indicating whether a REIT participates in the ENERGY STAR Partnership Program or not. CFP is measured by Tobin's Q, ROA and abnormal earnings. The authors find that Green REITs, which are found to have a larger share of their property portfolios certified, are associated with higher CFP.

Overall, the findings from the real estate related literature on the investigation of the CSP-CFP link confirm the results obtained from the finance literature. They show that GRI-based measures are a valid proxy for CSP and that Tobin's Q meets the requirements for an applicable CFP measure which reflects investors' sentiments. With regard to real estate, two studies were able to demonstrate that the financial advantages of a green property portfolio translate into an enhanced financial performance on the corporate level. This is a very important finding in support of the notion 
that, especially with regard to the real estate investment industry, sustainability on the product level, i.e. property level, positively affects financial returns on a corporate level.

The majority of the few studies in the real estate literature focus on U.S. companies and the one remaining study includes real estate service companies. In order to gain a more profound insight into the CSP-CFP link on a transcontinental level, it is therefore necessary to perform analyses with a broader international focus. This approach offers the opportunity of creating an exclusive sample of listed real estate investment companies of significant size. Moreover the utilization of the GRI Guidelines as a proxy for CSP needs to be investigated further, since GRI-aligned reporting offers a convenient and transparent way for listed real estate investment companies to report on sustainability issues.

This study contributes to the current academic debate in the real estate literature in five distinct ways. First, the study focuses solely on listed real estate investment companies whose primary objective is the long-term investment in and management of real estate. All other companies operating in the real estate investment industry, such as real estate investment service providers or home-builders, are excluded. By employing such a homogenous sample the study satisfies the claim for intra-industry analyses. Second, most of the existing empirical literature on the subject to date relies on samples taken from U.S. companies. The sample upon which this study is based, by contrast, includes firms from nine countries in Europe, North America and the Asia-Pacific region. Third, this study uses an index based on the GRI reporting framework and the associated Construction and Real Estate Sector Supplement in order to measure a listed real estate investment company's level of disclosure regarding issues of CSR. This approach ensures a precise, industry-specific and comprehensive measurement of both a company's engagement with and integration of CSR. Fourth, an objective method called component-wise gradient boosting is applied in order to identify the most value relevant CSR reporting content. Finally, the method of instrumental variable estimation is used to take into account the increasingly addressed issue of endogeneity.

\section{Hypotheses}

Based on the literature review above, this study addresses the question whether a positive relationship between CSP as measured by a score based on the GRI Guidelines as well as the respective Construction and Real Estate Supplement and CFP as measured by Tobin's Q can be established for a transcontinental sample of 191 listed real estate investment companies. The following hypothesis is put forward to empirically investigate the proposed link:

$H_{1}$ : The amount of disclosed CSR information by a listed real estate investment company is positively related to its market valuation.

The GRI reporting framework is a comprehensive tool to facilitate the dissemination of CSR information by companies as well as the reception of CSR information by 
internal and external stakeholders. However, companies from different industries are susceptible to different interests from external and internal stakeholders to different extents (Garcia-Castro et al. 2010; Cajias et al. 2011). Putting aside the GRI industry supplements, this raises the question as to whether the "one-size-fits-all" framework may also lead to an over-reporting on CSR issues and therefore dilute the effect of CSR information which is specifically relevant for the real estate investment industry.

As a consequence, it is of interest whether certain contents in disclosed CSR information are more value relevant for investors of listed real estate investment companies than others. It seems reasonable that, for instance, real estate specific CSR information has a larger or at least more significant association with the market value of a listed real estate investment company. Hence the following hypothesis is proposed:

$\mathrm{H}_{2}$ : A too comprehensive measurement of CSR mitigates the relationship between CSP and CFP for listed real estate investment companies.

The literature review revealed that accounting for endogeneity increasingly became a common feature of studies investigating the CSP-CFP link. Accordingly, this study also addresses the issue of endogeneity. Thus, a last hypothesis is established.

$H_{3}$ : Reverse causality is present in the relation between the amount of disclosed CSR information by a listed real estate investment company and its market valuation.

\section{Methodology}

Based on the theoretical considerations as well as the literature review above, the hypotheses stated in the previous section are tested by means of statistical data analysis. All statistical calculations are performed with R, a free software environment for statistical computing and graphics. ${ }^{2}$

The proposed hypotheses are tested in a cross-sectional regression framework using ordinary least-squares estimation (OLS). In a first step, Tobin's Q is regressed against a CSP score composed of all environmental and social GRI-performance indicators from the GRI Guidelines and the respective Construction and Real Estate Supplement and several control variables. In a further step the comprehensive CSP measure will be replaced by various sub-indices and more focused measures whose composition is explained in the following. Throughout the entire empirical analysis, all coefficient estimates are calculated based on standard errors robust to the presence of heteroscedasticity. The last part of the empirical study addresses the problem of endogeneity by applying the method of instrumental variables estimation and 2SLS.

\footnotetext{
${ }^{2}$ For further information on R see R Core Team (2013). Among other R add-on packages used, the most specific ones are ggplot2, mboost and tonymisc. For more information on $\mathrm{R}$ packages refer to the corresponding manuals available at http://cran.r-project.org/web/packages/.
} 


\section{Sample}

The universe from which the sample of listed REOCs and REITs is drawn comprises all active companies listed under the sectors "Real Estate Investment and Services" and "Real Estate Investment Trusts" of Thomson Reuters Datastream (TRD) as of June 2012. An additional prerequisite is that the firms' shares must be registered in a country where financial reporting of listed companies is required to be in line with the rules of the International Financial Accounting Standards (IFRS). The selected countries comprise Australia, Canada, France, Germany, Hong Kong, Netherlands, Singapore, Sweden and United Kingdom.

In order to ensure a homogenous sample with regard to company features and characteristics, certain qualifications have to be met. First, companies with a market capitalization of less than USD 50 million as of 31 December 2011 are not taken into account. ${ }^{3}$ Second, the minimum free float required to be included in the sample is set to $15 \%{ }^{4}$ This requirement secures a certain degree of "investibility" and excludes listed real estate companies owned by single parties which are believed not to underlie market competition for international institutional capital. In a third step, companies whose major field of business is different to the long-term investment in and the operating of real estate are removed from the initial sample. Examples of those companies are real estate development companies as well as real estate consulting companies and real estate service providers. The decision for or against a firm to be included in the sample is based on whether the item IAS 40 investment property is the largest item within non-current assets on the consolidated statement of financial position and on the company's strategy section in the annual report. In a last step, companies lacking data and annual reports in English are also excluded from the sample. ${ }^{5}$ Annual reports in English are a vital prerequisite in order to conduct a coherent content analysis with regard to the CSR variables. As a result, the final sample comprises 191 listed real estate investment companies (81 REOCs and 110 REITs) from nine different countries. (Fig. 1). Table 1 shows the composition of the final sample by country, REIT-status and aggregated market capitalization.

\section{Variable selection and definition}

Against the view of Callan and Thomas (2009) who argue that different measures have to be considered when investigating the CSP-CFP link, it is more important to avoid stakeholder mismatching as proposed by Wood and Jones (1995). In order to successfully investigate the CSP-CFP relationship it is therefore critical to employ one appropriate measure of CFP instead of various measures of CFP. The appropri-

\footnotetext{
${ }^{3}$ Exchange rates were retrieved for the 31 December 2011 from the official website of the Financial Management Service (FMS) which is a bureau of the United States Department of the Treasury.

${ }^{4}$ The requirements of a minimum market capitalization of USD 50 million and a minimum free float of $15 \%$ are in line with the rules for company inclusion of all four major indices provided by Global Property Research, a renowned provider of property indices.

${ }^{5}$ The provision of websites, financial reports and press releases in English is a general recommendation by the EPRA Best Practices Recommendations. For further information see EPRA (2011), p. 5.
} 


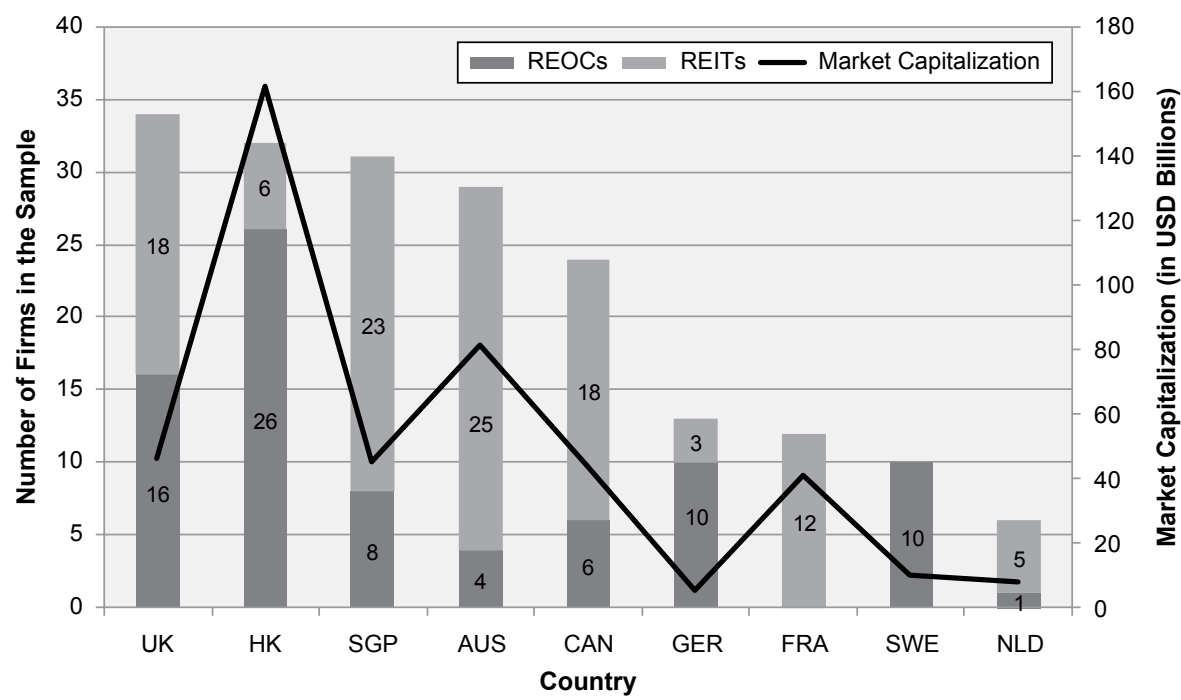

Fig. 1 Final sample by country, REIT-Status and aggregated market capitalization. (The values on the primary ordinate refer to the columns and the values on the secondary ordinate refer to the line. (Source: Own illustration))

ate CFP measure is Tobin's Q for two major reasons. First, Tobin's Q consists of two main components, i.e. market value and total assets. It is therefore possible to capture the intangible value of a company's CSR activities as indicated by a company's disclosures. Furthermore, Tobin's Q reflects the future benefits associated with a CSR engagement. Second, the denominator of Tobin's $Q$ which reflects replacement costs as proxied by total assets is particularly suited for listed real estate investment companies (Kohl and Schaefers 2012). Due to these companies' business strategy of holding properties long term, IAS 40 "investment property" is by far the largest item on the balance sheet. According to IFRS regulations, investment properties have to be recognized at fair value and therefore cannot be written off. Moreover, in the case of listed real estate investment companies, most of the future cash flows associated with intangible assets is already incorporated in the balance sheet, because these cash flows are reflected in the annual DCF-based valuation of investment properties. As a consequence, the difference between market value and total assets predominantly refers to future benefits from intangible assets such as good management or the incorporation of CSR into strategic management.

Three components are necessary to derive the variable for each company, i.e. market value, total debt and total assets. Since the share price and therefore the market value of a company change almost continuously, the closing price on the day 3 months after the fiscal year-end is chosen. The reason for this is that most stockexchanges require listed companies to issue an annual report within 3 months after the end of the fiscal year. This ensures that the latest financial accounting data and information on a firm's sustainability efforts is distributed and received by investors. As a consequence, the market value already reflects this information. A similar approach is followed by Schreck (2011). 
Table 1 Definition and sources of major variables used in this study. (Source: Own illustration)

\begin{tabular}{|c|c|c|}
\hline Variable & Definition & Source \\
\hline Tobin's Q & $\begin{array}{l}\text { Share price multiplied by the number of or- } \\
\text { dinary shares in issue plus total debt divided } \\
\text { by total assets }\end{array}$ & $\begin{array}{l}\text { Datastream/worldscope: Market value } \\
\text { (MV), total debt (WC03255), total as- } \\
\text { sets (WC02999) }\end{array}$ \\
\hline CSR83 & $\begin{array}{l}\text { CSR transparency score based on } 83 \text { GRI } \\
\text { indicators }\end{array}$ & Company reports and websites \\
\hline $\begin{array}{l}\text { ENV, LAB, } \\
\text { HR, SOI, PR }\end{array}$ & $\begin{array}{l}\text { CSR transparency score based on } 83 \text { GRI } \\
\text { indicators from the subsections "Envi- } \\
\text { ronmental", "Labor Practices and Decent } \\
\text { Work", "Human Rights", "Society" and } \\
\text { "Product Responsibility", }\end{array}$ & Company reports and websites \\
\hline CSR37 & $\begin{array}{l}\text { CSR transparency score based on } 37 \text { GRI } \\
\text { indicators }\end{array}$ & Company reports and websites \\
\hline CSR05 & $\begin{array}{l}\text { CSR transparency score based on } 5 \text { GRI } \\
\text { indicators }\end{array}$ & Company reports and websites \\
\hline $\operatorname{Iog}($ ASSETS $)$ & Natural logarithm of total assets & Worldscope: Total assets (WC02999) \\
\hline REIT & $\begin{array}{l}\text { Binary variable which takes the value } 1 \text { if } \\
\text { the company is a REIT and } 0 \text { otherwise }\end{array}$ & $\begin{array}{l}\text { Datastream: Industry Classification } \\
\text { Benchmark }\end{array}$ \\
\hline $\mathrm{ROA}(\mathrm{t})$ & Return on assets for the current period & $\begin{array}{l}\text { Worldscope: Return on assets } \\
\text { (WC08326) }\end{array}$ \\
\hline $\operatorname{ROA}(\mathrm{t}-1)$ & Return on assets for the previous period & $\begin{array}{l}\text { Worldscope: Return on assets } \\
\text { (WC08326) }\end{array}$ \\
\hline VOLA & $\begin{array}{l}\text { Standard deviation of share price based on } \\
\text { the last } 52 \text { weekly values, divided by the } \\
\text { mean price and multiplied by } 40\end{array}$ & Datastream: Volatility (VOL) \\
\hline LEV & Total debt / total assets & $\begin{array}{l}\text { Worldscope: Total debt (WC03255), } \\
\text { Total assets (WC02999) }\end{array}$ \\
\hline GR1_yrs & $\begin{array}{l}\text { Number of years for which a company has } \\
\text { reported in line with the GRI Guidelines }\end{array}$ & Company reports and websites \\
\hline
\end{tabular}

Since the fiscal year-ends vary between companies, four dates are considered in the sample: 30 June 2011, 30 November 2011, 31 December 2011 and 31 March 2012

In order to capture the amount of CSR relevant information provided by listed real estate investment companies and in order to make it comparable among firms, a CSR transparency score is developed. For the purpose of gaining a full insight into a company's CSR engagement, the underlying content analysis examines not only annual reports but in particular stand-alone CSR reports as well as corporate websites (Unerman 2000). There are various examples of studies using the technique of content analysis based on the GRI Guidelines in the literature on empirical research on CSR (Cajias et al. 2012; Cajias and Bienert 2011; Clarkson et al. 2008; Gamerschlag et al. 2011; Holder-Webb et al. 2009; Plumlee et al. 2010).

The variable CSR83 is a relative measure based on the 83 environmental and social GRI-performance indicators taken from the G3.1 Sustainability Reporting Guidelines and the Construction and Real Estate Sector Supplement. ${ }^{6}$ Following Gamerschlag et al. (2011), economic GRI-performance indicators are not considered,

\footnotetext{
${ }^{6}$ Although the G4 Guidelines were available during the time of data analysis, the G3.1 version was used, because the data is from 2011/2012 when G4 was still unavailable. As a consequence no company in the sample reported on the GRI-performance indicators firstly introduced in the G4 version. However, it is not expected that using the G4 Guidelines would alter the results in any way.
} 
as financial reporting according to IFRS is mandatory for all listed real estate investment companies in the sample. Appendix 1 contains a full list of these indicators and corresponding descriptions.

One point is assigned to a company for every GRI-performance indicator which is reported either fully or partially. A zero is allocated in all other cases. The CSRtransparency score CSR83 for a listed real estate investment company is calculated as follows:

$$
\text { CSR83 }=\frac{\text { number of reported } G R I-\text { performance indicators }}{\text { maximum number of achievable points }} .
$$

In the case of a company giving justified reasons for why certain indicators are not applicable and therefore not reported, the maximum number of achievable points is reduced by the number of substantiated omissions. CSR83 can take values between zero and one. The sub-indices ENV, LAB, HR, SOI and PR are analogously computed by dividing the number of reported GRI-performance indicators by the total number of achievable points in the respective sub-category.

However, the possibility of a problem related to the chosen method of measuring the sustainability of a listed real estate investment company cannot be excluded. A company achieving a high CSR83-score may not necessarily report exclusively on value relevant GRI-performance indicators. The question of whether comments on each and every GRI-performance indicator can be assumed to be value relevant can thus not be avoided. With regard to listed real estate investment companies in developed countries, it would, for instance, be rather precarious to ascribe a value relevance to the GRI-performance indicators HR6 or EN27 which require information on business conduct concerning the problem of child labor or packaging of products, respectively. Based on this notion, a strict and full compliance to the GRI Guidelines may lead to an over-estimation of sustainability, due to the reporting of information irrelevant to investors.

Furthermore, it is possible that two companies reporting on the same set of indicators achieve a different transparency score. This is the case when a company explicitly states that a certain indicator is not relevant or applicable in which case the denominator would be reduced by one. It is therefore easier for companies that exclude certain indicators to achieve a higher score although the amount of information provided does not exceed the amount provided by a company which reports on the same set of indicators yet without having excluded any others.

Consequently, a second set of GRI-performance indicators is created. CSR37 is derived in the same way as CSR83, but only refers to 37 GRI-performance indicators which are assumed to be of importance to the investors of listed real estate investment companies. The GRI-performance indicators included in this reduced measure are marked with a "yes" in column 3 of appendix 1. As all indicators are deemed value relevant, substantiated omissions reducing the maximum number of achievable points are not considered.

There is one major weakness in the previously described method of obtaining CSR37 and its respective sub-indices. Despite being based on reasonable grounds, the choice of GRI-performance indicators of supposed relevance for real estate 
Table 2 Summary of descriptive statistics

\begin{tabular}{llllll}
\hline Variable & Mean & Median & St. Dev. & Min & Max \\
\hline Tobin's Q & 0.776 & 0.806 & 0.188 & 0.186 & 1.341 \\
CSR83 & 0.126 & 0.060 & 0.182 & 0.000 & 0.986 \\
ENV & 0.138 & 0.057 & 0.191 & 0.000 & 0.963 \\
LAB & 0.161 & 0.063 & 0.207 & 0.000 & 0.000 \\
HR & 0.055 & 0.000 & 0.185 & 0.000 & 0.000 \\
SOI & 0.114 & 0.000 & 0.200 & 0.000 & 1.000 \\
PR & 0.123 & 0.100 & 0.189 & 0.000 & 1.000 \\
CSR37 & 0.210 & 0.108 & 0.241 & 0.000 & 1.000 \\
CSR05 & 0.360 & 0.400 & 0.325 & 0.000 & 1.000 \\
ASSETS & $5,682,569$ & $2,270,822$ & $9,832,494$ & 95,142 & $60,009,497$ \\
ROA $(t)$ & 6.834 & 6.120 & 5.601 & -8.520 & 48.750 \\
ROA $(t-1)$ & 5.318 & 5.250 & 5.426 & -24.010 & 26.280 \\
VOLA & 4.922 & 4.209 & 2.565 & 1.709 & 16.808 \\
LEV & 0.380 & 0.386 & 0.171 & 0.000 & 0.816 \\
\hline
\end{tabular}

St. Dev. standard deviation, Min and Max minimum and maximum values per variable

${ }^{a}$ The variable ASSETS is given in USD thousands

investment companies is, after all, discretionary. To weaken this argument, an additional method of identifying relevant GRI-performance indicators is applied which is fully based on a computational optimization algorithm. Generally, component-wise gradient boosting is a technique used to perform a variable selection based on the associated impact strength of explanatory variables on the dependent variable. The aim of this method is to find the optimal set of explanatory variables to predict an independent variable. In so doing, the method is able to test which GRI-performance indicators included in CSR37 are the most important. ${ }^{7}$ Analogous to the calculation of CSR83 and CSR37, the five most relevant GRI-performance indicators are chosen to create a new CSR-disclosure variable called CSR05.

The five GRI-performance indicators used to derive CSR05 based on the application of component-wise gradient boosting are marked with a "yes" in column 4 of appendix 1. The identified GRI-performance indicators come from the GRI-subcategories Product Responsibility, Environment and Labor Practices and Decent Work. This result suggests that in particular those indicators are value relevant which provide information on sustainability in the core-business of real estate investment companies, i.e. environmental sustainability in the real estate portfolio.

In order to prevent distorted results, a set of several control variables is included in the analyses. Table 1 provides a overview of all relevant variables used in the study as well as corresponding definitions and sources.

The summaries of descriptive statistics and the Pearson correlation matrix of all variables used throughout this study are depicted in Table 2 and Table 3, respectively.

\footnotetext{
${ }^{7}$ See Hofner et al. (2014) for a comprehensive introduction to component-wise gradient boosting and its application using R.
} 


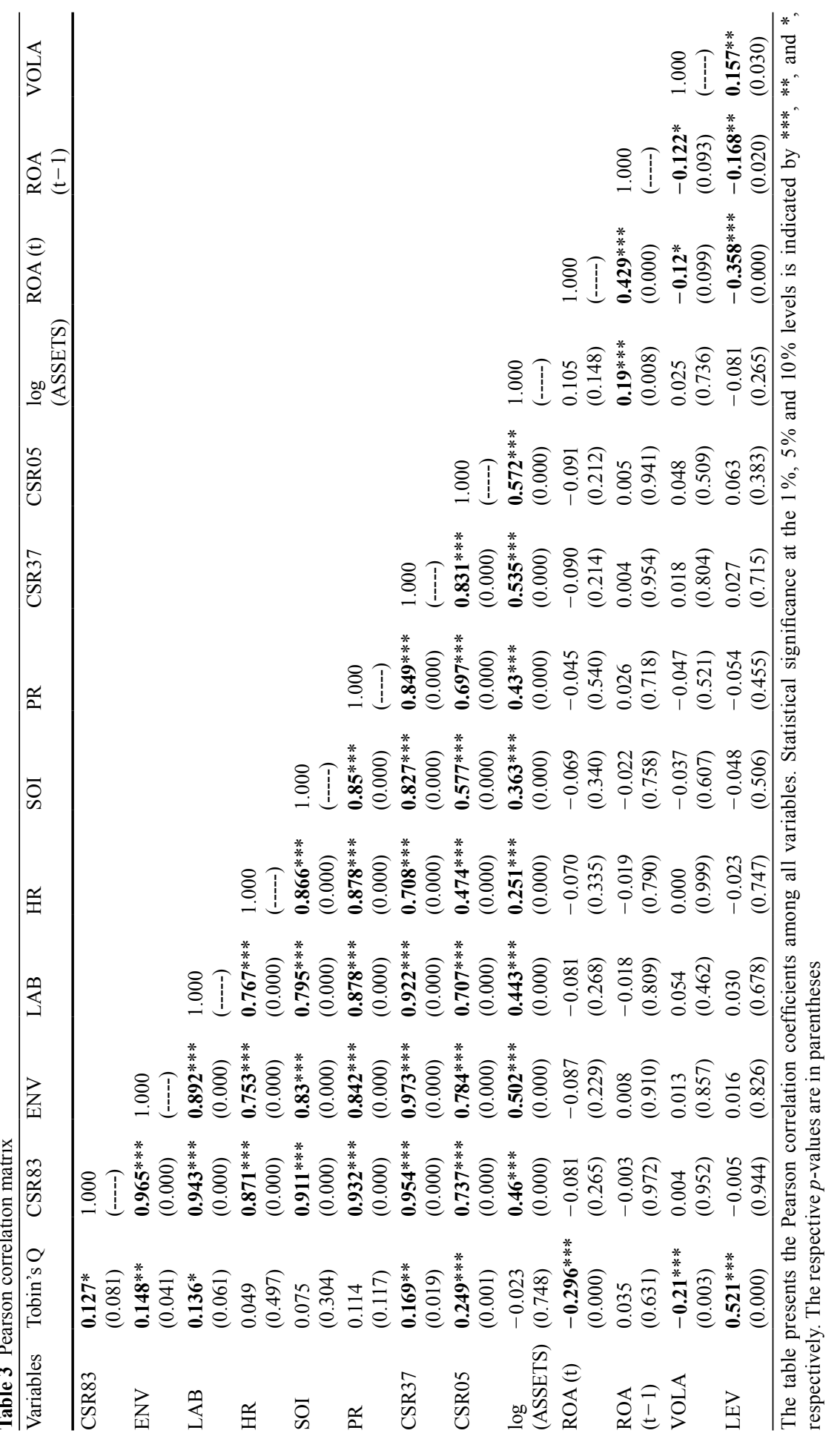




\section{Empirical results}

This section introduces the results of the cross-sectional regression analysis using OLS. Tobin's Q is regressed separately on CSR83 and its sub-indices as well as on a set of several control variables in models (1)-(6). Model (7) and model (8) introduces CSR37 and CSR05, respectively, to explain the variation in Tobin's Q. The results are presented in Table 4.

Model (1) represents the CSR83 base model. The coefficient estimate for CSR83 is 0.116 and statistically significant at the $5 \%$ level. The increase or decrease of CSR 83 is only possible by a multiple of $1205 \%$ points, because reporting on one more GRI-performance indicator invariably leads to an increase of $1205(=100 / 83)$ $\%$ points. According to the model, the additional reporting on one more GRI-performance indicator is on average associated with an increase of Tobin's Q by 0.002 holding all other factors constant. Thus, the theoretical difference in Tobin's Q of a company which fully reports on all GRI-performance indicators and a company which does not report on any GRI-performance indicators is 0.116 , all other factors held fixed. Models (2)-(6) are analogous to the base model but use the single components of CSR83 to explain the variation in Tobin's Q. The coefficient estimates for all sub-indices of CSR83 show positive signs as expected. However, even though the coefficient estimates for ENV, LAB and PR are statistically significant at least on the $5 \%$ level, it is not possible to reject the null hypothesis that the coefficient estimates of HR and SOI are different from zero. Insofar, when decomposing CSR83 into its main components, only ENV, LAB and PR seem to be value relevant.

Instead of CSR83 model (7) uses CSR37 as proxy for CSP. Besides the increased adjusted $\mathrm{R}^{2}(0.474)$ which provides evidence for a better model fit, also the coefficient estimate of CSR37 increases in magnitude and is now highly significant. In summary, using CSR37 instead of CSR83 yields more robust results. Taking into account the removal of the over-reporting bias, the general enhancement of the model can be considered as reasonable. Nonetheless, the method used to derive CSR37 is highly arbitrary and the doubts regarding its sufficiency cannot be dispelled. In view of these limitations, model (8) uses the computationally derived CSR05 variable which comprises the five most influential GRI-performance indicators. The five CSR-performance indicators can be found in column 5 of appendix 1 .

Using CSR05 as a proxy for CSP in model (8) improves the overall model fit further as the adjusted $\mathrm{R}^{2}$ is now 0.509 . As compared to model (7) both the magnitude as well as the significance of the CSP coefficient estimate increase. In conclusion, focusing on just a few very value relevant GRI-performance indicators yields more robust and less diluted results.

All control variables, except $\log$ (ASSETS), are statistically significant at least on the $10 \%$ level across all eight models. The variable $\log$ (ASSETS) only becomes significant in the CSR05 model. The insignificance of $\log$ (ASSETS) for most of the models mirrors the results of Callan and Thomas (2009) and Garcia-Castro et al. (2010). Across all models, REITs are supposed to show a Tobin's Q which is on average around 0.100 higher than the Tobin's Q for REOCs, holding all other factors constant. ROA of the current period is positively correlated with Tobin's Q, whereas ROA of the previous period is negatively correlated with Tobin's Q. However, the 


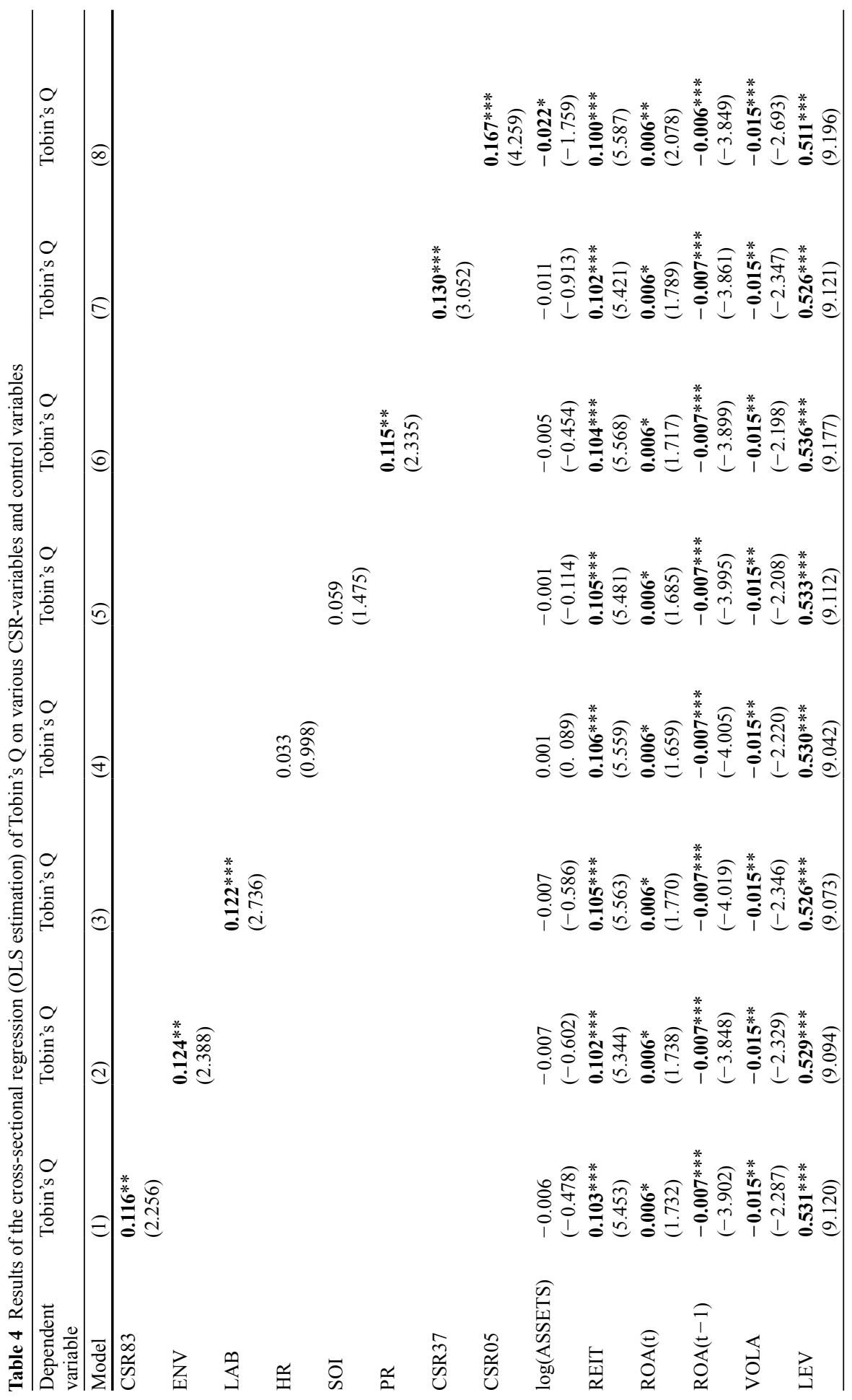




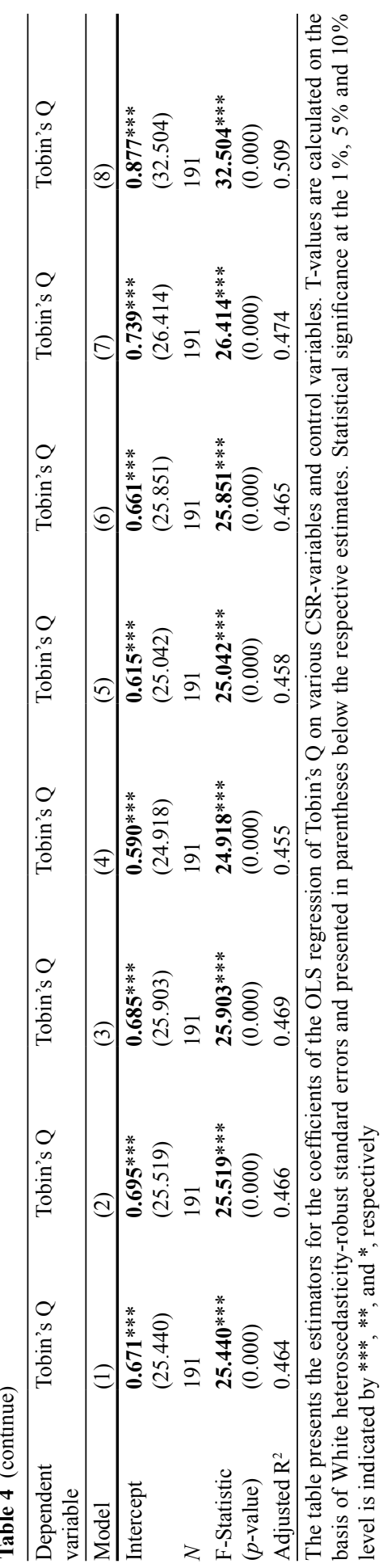


economic significance of both is rather low, given the very small values of the respective coefficient estimates. In line with various other empirical studies which also measure risk by the variation in stock returns, VOLA is negatively associated with Tobin's Q (Cajias et al. 2011; Cajias et al. 2012; Erhemjamts et al. 2013). LEV, however, is positively related to long-term financial profitability. This stands in contrast to the findings of Erhemjamts et al. (2013) and Schreck (2011) but corresponds to the findings of Garcia-Castro et al. (2010) and Cajias et al. (2011).

As has been shown, the problem of endogeneity is being increasingly addressed in studies examining the link between CSP and CFP. Hence, this study also takes this issue into account. With regard to the present problem, the structural form equation and the reduced form equation are:

$$
\begin{aligned}
\text { Tobins } Q= & \beta_{0}+\beta_{1} C S R 05+\beta_{2} \log (\text { ASSETS })+\beta_{3} R E I T+\beta_{4} R O A(t) \\
& +\beta_{5} R O A(t-1)+\beta_{6} V O L A+\beta_{7} L E V+u
\end{aligned}
$$

and

$$
\begin{aligned}
C S R 05 & =\beta_{0}+\beta_{1} G R I_{-} y r s+\beta_{2} \log (\text { ASSETS })+\beta_{3} R E I T+\beta_{4} R O A(t) \\
& +\beta_{5} R O A(t-1)+\beta_{6} V O L A+\beta_{7} L E V+u
\end{aligned}
$$

respectively.

In the case at hand, the variable CSR05 is suspected to be endogenous. The reason for this assumption goes back to the potential correlation between CSR05 and the error due to reverse causality. The variable GRI_yrs is defined as described in Table 1. It is assumed that after a listed real estate investment company has decided to address sustainability issues within the annual company reporting, the company's ability and willingness to report on CSR relevant matters increases over time. This means that the longer a company reports on CSR relevant issues, the higher the amount and quality of publicized CSR information. The variable GRI_yrs is thus taken to accurately predict CSR05 and in turn serves as an appropriate instrument for CSR05 (Table 5).

For the sake of clarity, model (1) illustrates the same model as model (8) in Table 4 which equals the structural form Eq. (2) in this case. Model (2) depicts the estimation results for the reduced form Eq. (3) using CSR05 as the dependent variable and GRI_yrs as the explanatory variable of interest or instrument, respectively. The coefficient estimate of GRI_yrs is 0.092 and is significant at the $1 \%$ level. This result suggests that listed real estate investment companies which report in accordance with the GRI Guidelines for many years are more likely to report on the five GRI-performance indicators which are included in CSR05. A glance at the estimator for $\log$ (ASSETS) reveals that larger firms show a higher propensity to report on the CSR05-indicators, as the coefficient estimate is positive and also significant at the $1 \%$ level. The F-statistic (which is not reported in the table) used to test the null hypothesis that the coefficient estimate of GRI_yrs is zero confirms the assumption of instrument relevance. It indicates a value of 22.264 which is well above the critical value of 10 as proposed by Stock and Watson (2007) and therefore rejects the null hypothesis of a weak instrument. With regard to the requirement of instrument exogeneity, it is not possible to conduct an empirical test since GRI_yrs is the only instrument and the model is 
Table 5 Results of the instrumental variable regression using GRI_yrs as an instrument for CSR05

\begin{tabular}{|c|c|c|c|c|}
\hline Dependent variable & Tobin's Q & CSR05 & Tobin's Q & Tobin's Q \\
\hline \multirow[t]{2}{*}{ Model } & & & (3) & (4) \\
\hline & Structural form & Reduced form & 2SLS & Hausman test \\
\hline CSR05 & $\begin{array}{l}\mathbf{0 . 1 6 7 * * *} \\
(4.259)\end{array}$ & & $\begin{array}{l}0.091 \\
(0.959)\end{array}$ & $\begin{array}{l}\mathbf{0 . 0 9 1} * \\
(1.749)\end{array}$ \\
\hline GRI_yrs & & $\begin{array}{l}\mathbf{0 . 0 9 2} * * * \\
(4.719)\end{array}$ & & \\
\hline Resid & & & & $\begin{array}{l}0.090 \\
(1.547)\end{array}$ \\
\hline $\log$ (ASSETS) & $\begin{array}{l}-\mathbf{0 . 0 2 2} * \\
(-1.759)\end{array}$ & $\begin{array}{l}\mathbf{0 . 1 1 9 * * *} \\
(8.276)\end{array}$ & $\begin{array}{l}-0.011 \\
(-0.688)\end{array}$ & $\begin{array}{l}\mathbf{0 . 0} \\
(-0.780)\end{array}$ \\
\hline REIT & $\begin{array}{l}\mathbf{0 . 1 0 0 * * *} \\
(5.587)\end{array}$ & $\begin{array}{l}0.022 \\
(0.624)\end{array}$ & $\begin{array}{l}\mathbf{0 . 1 0 3}^{* * *} \\
(4.905)\end{array}$ & $\begin{array}{l}\mathbf{0 . 1 0 3 * * *} \\
(5.573)\end{array}$ \\
\hline $\mathrm{ROA}(\mathrm{t})$ & $\begin{array}{l}\mathbf{0 . 0 0 6}^{* * * *} \\
(2.078)\end{array}$ & $\begin{array}{l}-0.002 \\
(-0.526)\end{array}$ & $\begin{array}{l}\mathbf{0 . 0 0 6} * * * \\
(-3.000)\end{array}$ & $\begin{array}{l}\mathbf{0 . 0 0 6 * *} \\
(1.980)\end{array}$ \\
\hline $\operatorname{ROA}(t-1)$ & $\begin{array}{l}-\mathbf{0 . 0 0 6} * * * \\
(-3.849)\end{array}$ & $\begin{array}{l}-\mathbf{0 . 0 0 5 *} \\
(-1.663)\end{array}$ & $\begin{array}{l}-\mathbf{0 . 0 0 7} * * * \\
(-3.500)\end{array}$ & $\begin{array}{l}-0.007 * * * \\
(-4.221)\end{array}$ \\
\hline VOLA & $\begin{array}{l}-\mathbf{0 . 0 1 5} * * * \\
(-2.693)\end{array}$ & $\begin{array}{l}0.005 \\
(0.644)\end{array}$ & $\begin{array}{l}-0.015 * * * \\
(-3.750)\end{array}$ & $\begin{array}{l}-\mathbf{0 . 0 1 5} * * * \\
(-2.640)\end{array}$ \\
\hline LEV & $\begin{array}{l}\mathbf{0 . 5 1 1} * * * \\
(9.196)\end{array}$ & $\begin{array}{l}0.157 \\
(1.477)\end{array}$ & $\begin{array}{l}\mathbf{0 . 5 1 9} * * * \\
(8.238)\end{array}$ & $\begin{array}{l}\mathbf{0 . 5 1 9 * * *} \\
(9.410)\end{array}$ \\
\hline Intercept & $0.877 * * *$ & $\begin{array}{l}-1.479 * * * \\
(-7.495)\end{array}$ & $\begin{array}{l}\mathbf{0 . 7 4 0 * * *} \\
(3.579)\end{array}$ & $\begin{array}{l}\mathbf{0 . 7 4 0 * * *} \\
(4.122)\end{array}$ \\
\hline $\mathrm{N}$ & & 191 & 191 & 191 \\
\hline F-Statistic & $32.504 * * *$ & $24.230 * * *$ & $28.770 * * *$ & $25.755 * * *$ \\
\hline ( $p$-value) & & $(0.000)$ & $(0.000)$ & $(0.000)$ \\
\hline Adjusted $\mathrm{R}^{2}$ & & 0.438 & 0.508 & 0.516 \\
\hline
\end{tabular}

The table presents the estimators for the coefficients of the OLS regression of both the structural form Eq. (8) and the reduced form Eq. (9). Model (3) illustrates the results of the 2SLS estimation. Model (4) gives test results for the regression-based Hausman test. T-values are calculated on the basis of White heteroscedasticity-robust standard errors and presented in parentheses below the respective estimates. Statistical significance at the $1 \%, 5 \%$ and $10 \%$ level is indicated by $* * *, * *$, and $*$, respectively

therefore exactly identified. However, Jo and Harjoto (2011) and Schreck (2009) suggest that the instrumental variable should have no influence on the dependent variable (here Tobin's Q), except indirectly through the endogenous variable (here CSR05). In line with this reasoning, Table 6 shows a very low and insignificant correlation between the variables GRI_yrs and Tobin's Q and a high and significant correlation between GRI_yrs and CSR05. Based on these findings and the theoretical argumentation above, GRI_yrs is assumed to be a relevant and exogenous instrument for CSR05.

Model (3) presents the results from the 2SLS estimation of model (1). While the coefficient estimates of the control variables are all significant at the $1 \%$ level and show the same signs as model (1), the coefficient estimates of the explanatory variable of interest, CSR05, turns insignificant with a $p$-value of 0.339 which is not reported in the table. The lower $t$-value which is the prerequisite for such a high $p$-value is due to the following reason: the magnitude of the 2SLS estimator decreased considerably while, at the same time, the standard error more than doubled. As a result, the low and positive effect of CSR05 is insignificant under 2SLS estimation. 
Table 6 Pearson correlation matrix of Tobin's Q, CSR05, and the instrument GRI_yrs

\begin{tabular}{lll}
\hline Variables & Tobin's Q & CSR05 \\
\hline CSR05 & $\mathbf{0 . 2 4 9}$ & 1.000 \\
& $(0.001)$ & $(----)$ \\
GRI_yrs & 0.065 & $\mathbf{0 . 4 9 0 * * *}$ \\
& $(0.374)$ & $(0.000)$ \\
\hline
\end{tabular}

The table presents the Pearson correlation coefficients among Tobin's Q, CSR05 and GRI_yrs. Statistical significance at the $1 \%, 5 \%$ and $10 \%$ level is indicated by $* * *, * *$, and $*$, respectively

In order to check for the presence of endogeneity, model (4) presents the results of the regression-based Hausman test as proposed by Wooldridge (2002). The regression-based Hausman test examines whether the OLS and the 2SLS estimator are significantly different. To test this, the residuals from the regression of the reduced form equation are included in the structural form equation as additional explanatory variable. The extended model is estimated using OLS. A statistically significant coefficient estimate for the residuals from the reduced form equation is proof of the presence of endogeneity. However, a glance at column (4) reveals that the relation between Tobin's Q and the explanatory variable resid is statistically not significant. As a consequence, the null hypothesis of no endogeneity cannot be rejected. This means that there is no evidence for the presence of reverse causality, given that GRI_ yrs is a relevant and exogenous instrument for CSR05.

In the context of this result, Wooldridge (2002) suggests relying on the OLS coefficient estimates as long as the null hypothesis of no endogeneity cannot be rejected. Based on this notion, the inference to be drawn is that OLS yields consistent and unbiased estimates since there is no evidence for simultaneous causality. OLS yields more efficient estimates than 2SLS when the endogenous variables are in fact exogenous (Wooldridge 2009).

\section{Concluding remarks}

This study set out to investigate the relationship between CSP and CFP for a sample of 191 listed real estate investment companies from nine different countries. In general, the results from the empirical analysis conducted do not lend support to the neo-classical idea that the engagement in CSR activities and the implementation of a comprehensive CSR strategy destroy shareholder wealth. In fact, it is rather the opposite that is true. With regard to listed real estate investment companies, evidence shows that there is strong reason to suggest that a convincing business case for CSR can be made.

Overall, a positive association can be observed between the amount of disclosed overall CSR information of a listed real estate investment company and its market valuation. Hypothesis $H_{1}$ can thus be confirmed. The result of model (1) in Table 4 shows that the association between CSP and CFP is positive and significant. However, using the different sub-indices of CSR83 yields mixed results. The reason for these heterogeneous results is that CSR engagements are in some areas given lower priority by investors of listed real estate investment companies and are therefore also valued lower. It is therefore argued that CSR83 also contains rather unimportant information. For that reason, the explanatory variables CSR37 and CSR05 were developed. Accord- 
ing to hypothesis $\mathrm{H}_{2}$, concentrating on less and, with regard to listed real estate investment companies, potentially more value relevant CSR information yields a more robust association between the amount of disclosed CSR information and market valuation. Using CSR37 and CSR05 instead of CSR83 as proxies for CSP results in a statistically more significant relationship of CSP and CFP.

On the basis of the empirical results of the Hausman test, it is not possible to substantiate any suspicion of endogeneity, given that GRI_yrs is a relevant and exogenous instrument for CSR05. As a result, the null hypothesis of the absence of endogeneity cannot be rejected. The validity of GRI_yrs has been properly tested and verified. Thus, it can be assumed that OLS yields consistent and unbiased estimates.

With regard to the CSP-CFP link, the indicator selection process based on the method of component-wise gradient boosting revealed that especially those indicators are deemed value relevant by investors which are directly linked to the core business of listed real estate investment companies. Here, the efforts of companies to mitigate environmental impacts by reducing resource and energy consumption of buildings and their associated cost-savings are identified as particularly value relevant. Based on this finding, it seems reasonable to infer that investors value CSR initiatives which have a clear and coherent link to the enhancement of future value creation processes.

In the case of listed real estate investment companies, a sustainable approach towards strategic management is rewarded by the capital markets. It therefore makes sense for business executives of such companies to implement appropriate CSR strategies into their core business functions. In order to reap the benefits from these activities, a listed real estate company has to report on its CSR engagements in detail and make this information public in a structured way. With regard to the implemented CSR strategy, a focus should be put on areas which directly relate to the core business and entail future cost advantages such as the investment into sustainable buildings or the enhancement of energy efficiency in portfolio properties. Reporting such efforts effectively is then key to enjoying the benefits of an enhanced valuation by capital markets.

Future research may increasingly draw on panel data approaches. However, the number of listed real estate investment companies worldwide which report on CSR issues using the GRI Guidelines is still rather low and has been even lower in the past. It is likely to take a few more years until a data base will be available which is large enough to allow for the use of more sophisticated statistical techniques while considering CSR engagements of listed real estate investment companies in detail and in line with the GRI Guidelines. Furthermore, an integration of countries like the United States and Japan whose accounting rules are not yet fully aligned to IFRS would be desirable but will remain difficult. Another important aspect which has to be taken into account in future research is the focusing on CSR areas which are indeed value relevant for listed real estate investment companies.

Open Access This article is distributed under the terms of the Creative Commons Attribution 4.0 International License (http://creativecommons.org/licenses/by/4.0/), which permits use, duplication, adaptation, distribution, and reproduction in any medium or format, as long as you give appropriate credit to the original author(s) and the source, provide a link to the Creative Commons license, and indicate if changes were made. 


\section{Appendix 1}

List of Employed GRI-Performance Indicators Including Corresponding Descriptions and Their Respective Inclusion in the Sustainability Measures CSR83, CSR37 and CSR05. (Source: Own illustration following GRI (2011))

\begin{tabular}{|c|c|c|c|}
\hline & Environmental (EN) & CSR37 & CSR05 \\
\hline \multicolumn{4}{|c|}{ Materials } \\
\hline EN1 & Materials used by weight, value or volume & & \\
\hline EN2 & $\begin{array}{l}\text { Percentage of materials used that are recycled and reused input } \\
\text { materials }\end{array}$ & & \\
\hline \multicolumn{4}{|c|}{ Energy } \\
\hline EN3 & Direct energy consumption by primary energy source & Yes & \\
\hline EN4 & Indirect energy consumption by primary source & Yes & \\
\hline CRE1 & Building energy intensity & Yes & \\
\hline EN5 & Energy saved due to conservation and efficiency improvements & Yes & \\
\hline EN6 & $\begin{array}{l}\text { Initiatives to provide energy-efficient or renewable energy based } \\
\text { products and services, and reductions in energy requirements as a } \\
\text { result of these initiatives }\end{array}$ & Yes & Yes \\
\hline EN7 & $\begin{array}{l}\text { Initiatives to reduce indirect energy consumption and reductions } \\
\text { achieved }\end{array}$ & Yes & Yes \\
\hline \multicolumn{4}{|l|}{ Water } \\
\hline EN8 & Total water withdrawal by source & Yes & \\
\hline EN9 & Water sources significantly affected by withdrawal of water & & \\
\hline EN10 & Percentage and total volume of water recycled and reused & Yes & \\
\hline CRE2 & Building water intensity & Yes & \\
\hline \multicolumn{4}{|c|}{ Biodiversity } \\
\hline EN11 & $\begin{array}{l}\text { Location and size of land owned, leased, managed in, or adjacent to, } \\
\text { protected areas and areas of high biodiversity value outside protected } \\
\text { areas }\end{array}$ & & \\
\hline EN12 & $\begin{array}{l}\text { Description of significant impacts of activities, products, and services } \\
\text { on biodiversity in protected areas and areas of high biodiversity value } \\
\text { outside protected areas }\end{array}$ & & \\
\hline EN13 & Habitats protected or restored & & \\
\hline EN14 & $\begin{array}{l}\text { Strategies, current actions, and future plans for managing impacts on } \\
\text { biodiversity }\end{array}$ & & \\
\hline EN15 & $\begin{array}{l}\text { Number of IUCN Red List species and national conservation list } \\
\text { species with habitats in areas affected by operations, by level of } \\
\text { extinction risk }\end{array}$ & & \\
\hline \multicolumn{4}{|c|}{ Emissions, effluents and waste } \\
\hline EN16 & Total direct and indirect greenhouse gas emissions by weight & Yes & \\
\hline EN17 & Other relevant indirect greenhouse gas emissions by weight & Yes & \\
\hline CRE3 & Greenhouse gas emissions intensity from buildings & Yes & \\
\hline CRE4 & $\begin{array}{l}\text { Greenhouse gas emissions intensity from new construction and rede- } \\
\text { velopment activity }\end{array}$ & Yes & \\
\hline EN18 & $\begin{array}{l}\text { Initiatives to reduce greenhouse gas emissions and reductions } \\
\text { achieved }\end{array}$ & Yes & \\
\hline EN19 & Emissions of ozone-depleting substances by weight & & \\
\hline EN20 & NOx, SOx, and other significant air emissions by type and weight & & \\
\hline
\end{tabular}




\begin{tabular}{|c|c|c|c|}
\hline & Environmental (EN) & CSR37 & CSR05 \\
\hline$\overline{\mathrm{EN} 21}$ & Total water discharge by quality and destination & & \\
\hline EN22 & Total weight of waste by type and disposal method & Yes & \\
\hline EN23 & Total number and volume of significant spills & & \\
\hline EN24 & $\begin{array}{l}\text { Weight of transported, imported, exported, or treated waste deemed } \\
\text { hazardous under the terms of the Basel Convention Annex I, II, III, } \\
\text { and VIII, and percentage of transported waste shipped internationally }\end{array}$ & & \\
\hline EN25 & $\begin{array}{l}\text { Identity, size, protected status, and biodiversity value of water bodies } \\
\text { and related habitats significantly affected by the reporting organiza- } \\
\text { tion's discharges of water and runoff }\end{array}$ & & \\
\hline \multicolumn{4}{|c|}{ Land degradation, contamination and remediation } \\
\hline CRE5 & $\begin{array}{l}\text { Land and other assets remediated and in need of remediation for } \\
\text { the existing or intended land use according to applicable legal } \\
\text { designations }\end{array}$ & Yes & \\
\hline \multicolumn{4}{|c|}{ Products and services } \\
\hline EN26 & $\begin{array}{l}\text { Initiatives to enhance efficiency and mitigate environmental impacts } \\
\text { of products and services, and extent of impact mitigation }\end{array}$ & Yes & Yes \\
\hline EN27 & $\begin{array}{l}\text { Percentage of products sold and their packaging materials that are } \\
\text { reclaimed by category }\end{array}$ & & \\
\hline \multicolumn{4}{|c|}{ Compliance } \\
\hline EN28 & $\begin{array}{l}\text { Monetary value of significant fines and total number of non-mon- } \\
\text { etary sanctions for non-compliance with environmental laws and } \\
\text { regulations }\end{array}$ & Yes & \\
\hline \multicolumn{4}{|c|}{ Transport } \\
\hline EN29 & $\begin{array}{l}\text { Significant environmental impacts of transporting products and other } \\
\text { goods and materials used for the organization's operations, and trans- } \\
\text { porting members of the workforce }\end{array}$ & & \\
\hline \multicolumn{4}{|c|}{ Overall } \\
\hline EN30 & Total environmental protection expenditures and investments by type & & \\
\hline \multicolumn{4}{|c|}{ Social: labor practices and decent work (LAB) } \\
\hline \multicolumn{4}{|c|}{ Employment } \\
\hline LA1 & $\begin{array}{l}\text { Total workforce by employment type, employment contract, and } \\
\text { region, broken down by gender }\end{array}$ & Yes & \\
\hline LA2 & $\begin{array}{l}\text { Total number and rate of new employee hires and employee turnover } \\
\text { by age group, gender, and region }\end{array}$ & Yes & \\
\hline LA3 & $\begin{array}{l}\text { Benefits provided to full-time employees that are not provided to } \\
\text { temporary or part-time employees, by major operations }\end{array}$ & Yes & Yes \\
\hline LA15 & Return to work and retention rates after parental leave, by gender & Yes & \\
\hline \multicolumn{4}{|c|}{ Labor/management relations } \\
\hline LA4 & Percentage of employees covered by collective bargaining agreements & & \\
\hline LA5 & $\begin{array}{l}\text { Minimum notice period(s) regarding significant operational changes, } \\
\text { including whether it is specified in collective agreements }\end{array}$ & & \\
\hline \multicolumn{4}{|c|}{ Occupational health and safety } \\
\hline LA6 & $\begin{array}{l}\text { Percentage of total workforce represented in formal joint manage- } \\
\text { ment-worker health and safety committees that help monitor and } \\
\text { advise on occupational health and safety programs }\end{array}$ & & \\
\hline LA7 & $\begin{array}{l}\text { Rates of injury, occupational diseases, lost days, and absenteeism, and } \\
\text { number of work-related fatalities by region and by gender }\end{array}$ & & \\
\hline CRE6 & $\begin{array}{l}\text { Percentage of the organization operating in verified compliance with } \\
\text { an internationally recognized health and safety management system }\end{array}$ & & \\
\hline LA8 & $\begin{array}{l}\text { Education, training, counseling, prevention, and risk-control programs } \\
\text { in place to assist workforce members, their families, or community } \\
\text { members regarding serious diseases }\end{array}$ & & \\
\hline
\end{tabular}




\begin{tabular}{llll}
\hline & Environmental (EN) & CSR37 & CSR05 \\
\hline LA9 & $\begin{array}{l}\text { Health and safety topics covered in formal agreements with trade } \\
\text { unions }\end{array}$ & & \\
\hline
\end{tabular}

Training and education

LA10 Average hours of training per year per employee by gender, and by Yes employee category

LA11 Programs for skills management and lifelong learning that support the Yes continued employability of employees and assist them in managing career endings

LA12 Percentage of employees receiving regular performance and career Yes development reviews, by gender

Diversity and equal opportunity

LA13 Composition of governance bodies and breakdown of employees per Yes employee category according to gender, age group, minority group membership, and other indicators of diversity

Equal remuneration for women and men

LA14 Ratio of basic salary and remuneration of women to men by employee Yes category, by significant locations of operation

Social: Human Rights (HR)

Investment and procurement practices

HR1 Percentage and total number of significant investment agreements and contracts that include clauses incorporating human rights concerns, or that have undergone human rights screening

HR2 Percentage of significant suppliers, contractors and other business partners that have undergone human rights screening, and actions taken

HR3 Total hours of employee training on policies and procedures concerning aspects of human rights that are relevant to operations, including the percentage of employees trained

Non-discrimination

HR4 Total number of incidents of discrimination and corrective actions taken

Freedom of association and collective bargaining

HR5 Operations and significant suppliers identified in which the right to exercise freedom of association and collective bargaining may be violated or at significant risk, and actions taken to support these rights

Child labor

HR6 Operations and significant suppliers identified as having significant risk for incidents of child labor, and measures taken to contribute to the effective abolition of child labor

Forced and compulsory labor

HR7 Operations and significant suppliers identified as having significant risk for incidents of forced or compulsory labor, and measures to contribute to the elimination of all forms of forced or compulsory labor

Security practices

HR8 Percentage of security personnel trained in the organization's policies or procedures concerning aspects of human rights that are relevant to operations

Indigenous rights

HR9 Total number of incidents of violations involving rights of indigenous people and actions taken

Assessment

HR10 Percentage and total number of operations that have been subject to human rights reviews and/or impact assessments 


$$
\text { Environmental (EN) }
$$

CSR37 CSR05

Remediation

HR11 Number of grievances related to human rights filed, addressed and resolved through formal grievance mechanisms

Social: Society (SOI)

Local communities

SO1 Percentage of operations with implemented local community engage- Yes ment, impact assessments, and development programs

SO9 Operations with significant potential or actual negative and positive Yes impacts on local communities

SO10 Prevention and mitigation measures implemented in operations with significant potential or actual negative impacts on local communities

CRE7 Number of persons voluntarily and involuntarily displaced and/or resettled by development, broken down by project

\section{Corruption}

SO2 Percentage and total number of business units analyzed for risks Yes related to corruption

SO3 Percentage of employees trained in organization's anti-corruption Yes policies and procedures

SO4 Actions taken in response to incidents of corruption.

Public policy

SO5 Public policy positions and participation in public policy development and lobbying

SO6 Total value of financial and in-kind contributions to political parties, politicians, and related institutions by country

Anti-competitive behavior

SO7 Total number of legal actions for anti-competitive behavior, anti-trust, and monopoly practices and their outcomes

Compliance

SO8 Monetary value of significant fines and total number of non-monetary Yes sanctions for non-compliance with laws and regulations

Social: Product responsibility $(P R)$

Customer health and safety

PR1 Life cycle stages in which health and safety impacts of products and services are assessed for improvement, and percentage of significant products and services categories subject to such procedures

PR2 Total number of incidents of non-compliance with regulations and voluntary codes concerning health and safety impacts of products and services during their life cycle, by type of outcomes

Product and service labelling

PR3 Type of product and service information required by procedures, and percentage of significant products and services subject to such information requirements

CRE8 Type and number of sustainability certification, rating and labeling schemes for new construction, management, occupation and redevelopment

PR4 Total number of incidents of non-compliance with regulations and voluntary codes concerning product and service information and labeling, by type of outcomes

PR5 Practices related to customer satisfaction, including results of surveys Yes measuring customer satisfaction 


\begin{tabular}{|c|c|c|c|}
\hline & Environmental (EN) & CSR37 & CSR05 \\
\hline \multicolumn{4}{|c|}{ Marketing communications } \\
\hline PR6 & $\begin{array}{l}\text { Programs for adherence to laws, standards, and voluntary codes re- } \\
\text { lated to marketing communications, including advertising, promotion, } \\
\text { and sponsorship }\end{array}$ & & \\
\hline PR7 & $\begin{array}{l}\text { Total number of incidents of non-compliance with regulations and } \\
\text { voluntary codes concerning marketing communications, including } \\
\text { advertising, promotion, and sponsorship by type of outcomes }\end{array}$ & & \\
\hline \multicolumn{4}{|c|}{ Customer privacy } \\
\hline PR8 & $\begin{array}{l}\text { Total number of substantiated complaints regarding breaches of cus- } \\
\text { tomer privacy and losses of customer data }\end{array}$ & & \\
\hline \multicolumn{4}{|c|}{ Compliance } \\
\hline PR9 & $\begin{array}{l}\text { Monetary value of significant fines for non-compliance with laws and } \\
\text { regulations concerning the provision and use of products and services }\end{array}$ & & \\
\hline
\end{tabular}

The table gives an overview of all environmental and social GRI-performance indicators based on the G3.1 Sustainability Reporting Guidelines and the Construction and Real Estate Sector Supplement. All 83 indicators are included in the CSR83 measure. The last two columns highlight those indicators which are included in the CSR 37 and CSR05 measure, respectively

\section{References}

Cajias, M., \& Bienert, S. (2011). Does sustainability pay off for European listed real estate companies? The dynamics between risk and provision of responsible information. Journal of Sustainable Real Estate, 3(1), 211-231.

Cajias, M., Fuerst, F., McAllister, P., \& Nanda, A. (2011). Do responsible real estate companies outperform their peers? papers.ssrn.com/sol3/Delivery.cfm/SSRN_ID1920225_code377440. pdf?abstractid=1808701\&mirid=1. Accessed 25 July 2012.

Cajias, M., Geiger, P., \& Bienert, S. (2012). Green agenda and green performance: Empirical evidence for real estate companies. Journal of Real Estate Research, 5(2), 135-155.

Callan, S. J., \& Thomas, J. M. (2009). Corporate financial performance and corporate social performance: An update and reinvestigation. Corporate Social Responsibility and Environmental Management, 16(2), 61-78.

Clarkson, P. M., Li, Y., Richardson, G. D., \& Vasvari, F. P. (2008). Revisiting the relation between environmental performance and environmental disclosure: An empirical analysis. Accounting, Organizations and Society, 33(4-5), 303-327.

Dermisi, S. V. (2009). Effect of LEED ratings and levels on office property assessed and market values. Journal of Sustainable Real Estate, 1(1), 23-47.

Eichholtz, P., Kok, N., \& Yonder, E. (2012). Portfolio greenness and the financial performance of REITs. Journal of International Money and Finance, 31(7), 1911-1929.

Eichholtz, P., Kok, N., \& Quigley, J. M. (2013). The economics of green buildings. The Review of Economics and Statistics, 95(1), 50-63.

EPRA (European Public Real Estate Association) (2011). EPRA reporting: Best practices recommendations. http://www.epra.com/media/EPRA_BPR_2011.pdf. Accessed:17. Juli 2012.

Erhemjamts, O., Li, Q., \& Venkateswaran, A. (2013). Corporate social responsibility and its impact on firms' investment policy, organizational structure, and performance. Journal of Business Ethics, $118(2), 395-412$.

Fuerst, F. , \& Mcallister, P. (2011). Green noise or green value? Measuring the effects of environmental certification on office values. Real Estate Economics, 29(1), 46-69.

Gamerschlag, R., Möller, K., \& Verbeeten, F. (2011). Determinants of voluntary CSR disclosure: Empirical evidence from Germany. Review of Managerial Science, 5(2-3), 233-262.

Garcia-Castro, R., Ariño, M. A., \& Canela, M. A. (2010). Does social performance really lead to financial performance? Accounting for endogeneity. Journal of Business Ethics, 92(1), 107-126.

Global sustainable investment Alliance. (2013). Global sustainable investment review 2012. http://ussif. org/resources/req/?fileID=16. Accessed 14 Feb 2013. 
GRI (Global Reporting Initiative) (2014). GRI sustainability disclosure database. database.globalreporting.org.

Holder-Webb, L., Cohen, J. R., Nath, L., \& Wood, D. (2009). The supply of corporate social responsibility disclosures among U.S. firms. Journal of Business Ethics, 84(4), 497-527.

Hofner, B., Mayr, A., Robinzonov, N., \& Schmid, M. (2014). Model-based boosting in R: A hands-on tutorial using the R package mboost. Computational statistics, 29(3), 3-35.

Jo, H., \& Harjoto, M. A. (2011). Corporate governance and firm value: The impact of corporate social responsibility. Journal of Business Ethics, 103, 351-383.

Kohl, N., \& Schaefers, W. (2012). Corporate governance and market valuation of publicly traded real estate companies: Evidence from Europe. The Journal of Real Estate Finance and Economics, 44(3), 362-393.

Margolis, J. D., Elfenbein, H. A., \& Walsh, J. P. (2009). Does it pay to be good ... and does it matter? A meta-analysis and redirection of research on the relationship between corporate social and financial performance. http://papers.ssrn.com/sol3/Delivery.cfm/SSRN_ID1866371_code330833.pdf?abstrac tid $=1866371 \&$ mirid $=3$. Accessed 27 Sept 2011.

McKinsey \& Company. (2007). Shaping the new rules of competition: UN global compact participant mirror. http://www.unglobalcompact.org/docs/summit2007/mckinsey_embargoed_until020707.pdf. Accessed 19 July 2011.

Orlitzky, M., Schmidt, F. L., \& Rynes, S. L. (2003). Corporate social and financial performance: A metaanalysis. Organization Studies, 24(3), 403-441.

Plumlee, M., Brown, D., Hayes, R. M., \& Marshall, R. S. (2010). Voluntary environmental disclosure quality and firm value: Further evidence. papers.ssrn.com/abstract_id=1744114. Accessed 12 April 2012.

Porter, M. E., \& Kramer, M. R. (2006). Strategy and society: The link between competitive advantage and corporate social responsibility. Harvard Business Review, 84(12), 78-92.

$\mathrm{R}$ Core Team. (2013). R: A language and environment for statistical computing. Vienna: R Foundation for Statistical Computing.

Reichardt, A., Fuerst, F., Rottke, N. B., \& Zietz, J. (2012). Sustainable building certification and rent premium: A panel data approach. The Journal of Real Estate Research, 34(1), 99-126.

Sah, V., Miller, N. G., \& Ghosh, B. (2013). Are green REITs valued more? Journal of Real Estate Portfolio Management, 19(2), 169-177.

Schreck, P. (2009). The business case for corporate social responsibility: Understanding and measuring economic impacts of corporate social performance. Heidelberg: Physica-Verlag.

Schreck, P. (2011). Reviewing the business case for corporate social responsibility: New evidence and analysis. Journal of Business Ethics, 103(2), 167-188.

Stock, J. H., \& Watson, M. W. (2007). Introduction to econometrics. Boston: Pearson Addison-Wesley.

UNEP (United Nations Environment Programme) (2009). Buildings and climate change: Summary for decision-makers. http://www.unep.org/SBCI/pdfs/SBCI-BCCSummary.pdf. Accessed 16 April 2012.

Unerman, J. (2000). Methodological issues: Reflections on quantification in corporate social reporting content analysis. Accounting, Auditing \& Accountability Journal, 13(5), 667-680.

USGBC (United States Green Building Council) (2008). A national green building agenda. www.usgbc. org/sites/default/files/Docs3402.pdf. Accessed 21 Feb 2014.

van Marrewijk, M. (2003). Concepts and definitions of CSR and corporate sustainability: Between agency and communion. Journal of Business Ethics, 44(2-3), 95-105.

Wood, D. J., \& Jones, R. E. (1995). Stakeholder mismatching: A theoretical problem in empirical research on corporate social performance. The International Journal of Organizational Studies, 3(3), 229-267.

Wooldridge, J. M. (2002). Econometric analysis of cross section an panel data. Cambridge: MIT Press.

Wooldridge, J. M. (2009). Introductory econometrics: A modern approach. Mason: Cengage Learning. 